\title{
INTEGRALITAS SISTEM SANAD DAN KONTEKSTUALISASI PEMAHAMAN HADIS VERSUS KONSEP SUNAH MUHAMMAD SHAHRÛR
}

\author{
Amrulloh \\ Universitas Pesantren Tinggi Darul Ulum (Unipdu) Jombang, Indonesia \\ E-mail: amrulloh@pps.unipdu.ac.id
}

\begin{abstract}
This article discusses the concept of Sunna promoted by Muhammad Shahrûr, one of the most controversial contemporary Islamic scholars of Syrian Islamic thought, as well as his critical study. Here the author attempts to expose the unappreciative attitude of Shahrûr to the existence of the sanad system which is an integral part of the construction of the criticism of the Hadith. In fact, at the same time, he made the Hadith as the basis for the inference of the maximum limits of a law in its boundary theory. By describing, analyzing and then criticizing the views of the Shahrûr on the concept of the Sunna, the authors came to the conclusion that the Shahrûr lawsuit against the existence of the Hadith Sciences and its lack of appreciation of the sanad system is not necessary.
\end{abstract}

Keywords: Sanad System, Contextual, Sunna, Hadith.

\section{Pendahuluan}

Selain otoritas tafsir dan fikih, satu lagi yang secara langsung digugat oleh Muhammad Shahrûr, seperti ditegaskan Dale F. Eickelman, adalah otoritas Hadis. ${ }^{1}$ Sebagian dan sementara kalangan menganggap bahwa

\footnotetext{
1 Dale F. Eickelman, "Foreword," dalam Andreas Christmann (ed), The Qur'an, Morality and Critical Reason: The Essential Mubammad Shahrur (Leiden: Brill, 2009), ix. 
hadis-hadis Nabi yang tercatat dalam kitab-kitab Hadis kanonik, seperti Sabîth al-Bukbârî, Sabị̂̂ Muslim, Sunan Abî Dâwud, Sunan al-Tirmidbî, Sunan al-Nasâ' Ilahi. Rasulullah tidak mengucapkan segala sesuatu kecuali berdasarkan wahyu Ilahi. Perspektif yang populer dalam dunia pemikiran Islam ini memang masih perlu untuk dikritisi. Realitasnya, terdapat hadis-hadis yang tidak bisa dikatakan bahwa ia bersumber dari wahyu Ilahi. Jika demikian realitasnya, maka pemahaman tekstual terhadap Hadis juga harus dibongkar dan dikritisi secara mendalam. Tentunya itu harus dilakukan secara hati-hati dan komprehensif, sebab banyak juga hadis yang hendaknya tetap dipahami secara tekstual.

Kritik Hadis dan kodifikasinya juga tidak jarang menimbulkan persoalan yang sejak kemunculannya hingga saat ini tetap menjadi perdebatan sengit. Realitasnya -walaupun banyak sarjana Muslim, baik klasik maupun modern, yang telah berupaya untuk mengompromikannya dengan pembolehan beliau- Rasulullah pernah melarang para sahabat untuk menulis Hadis.

Muḥammad Shaḥrûr, seorang intelektual Muslim yang basis bidang keilmuannya adalah teknik dan pernah mengenyam pendidikan tingginya di Moskow dan Dublin, berupaya untuk membongkar pemahamanpemahaman lama yang tersemat dalam kajian-kajian kehadisan. Memahami secara kritis pandangan-pandangan Shạrûr tentang Sunah dan Hadis serta segala yang berkaitan dengannya -seperti kritiknya, sistem sanadnya, pemahamannya dan lain sebagainya- menjadi penting. Dengan metode deskriptif-analitis-kritis, di sini penulis berupaya mendudukkan dan menimbang pandangan-pandangan kehadisan Shahrûr, sehingga yang dianggap layak bisa diperhitungkan untuk diterapkan, dan yang dianggap tidak layak diterapkan bisa dipandang secara kritis dan selanjutnya bisa diabaikan.

\section{Sekilas Biografi Muhammad Shặrûr}

Muhammad Shậûr lahir pada tahun 1938 Masehi dari seorang ayah yang konservatif ${ }^{2}$ dan taat menjalankan ritual agama Islam namun tetap menjunjung tinggi rasionalitas serta objektivitas hukum alam, serta dari seorang ibu yang buta huruf. Ia dilahirkan di daerah Ṣaliḥiyah, Damaskus, Suriah. Sebab lemahnya ekonomi keluarga, Shaḥrûr kecil sempat berniat

\footnotetext{
2 Label "konservatif" ini disematkan oleh Shậûr sendiri untuk menggambarkan ayahnya yang gigih dan keras dalam menjalankan ritual keagamaan, misalnya salat, puasa dan haji. Pada tahun 1946, ketika Shaḥûr berumur 8 tahun, ia mengerjakan ibadah haji ke Mekah bersama ayahnya.
} 
untuk putus sekolah dan berkeinginan untuk bekerja, namun keinginannya itu tidak disetujui oleh orangtuanya, terutama ibunya. Di masa kanak-kanak dan remajanya, Shahrûr begitu dekat dengan ayahnya yang banyak mengajarinya kebijaksanaan. Sekali waktu, dengan menunjuk pada sebuah perapian, ayahnya berkata pada Shahrûr kecil: "Jika kamu hendak. menghangatkan badan, jangan membaca Al-Qur'an, tapi nyalakanlah api di perapian itu. ’’ Tidak mengherankan jika kemudian Shahrûr diarahkan ke pendidikan umum untuk belajar sains dari pada ke sekolah keagamaan, baik formal maupun informal (madrasah atau kuttâb).

Setelah melewati masa remaja di Suriah, pada tahun 1958 Shaḥrûr melanjutkan studinya ke Rusia setelah lulus seleksi. Ia sebenarnya tidak memilih Rusia secara spesifik sebagai pelabuhan studi lanjutnya. Ia hanya ingin mengenyam ilmu pengetahuan di bangku universitas luar negeri yang kebetulan adalah Rusia. Selama di Rusia inilah Shạhrûr banyak bersentuhan dengan filsafat Marxisme sebagai konsekuensi logis dari keingintahuannya tentang masyarakat Rusia dari berbagai aspeknya, baik budaya, sosial, politik, ekonmi dan seterusnya. Puncak kegelisahan Shaḥrûr menyeruak ketika Persatuan Republik Arab bubar. Jika sebelumnya ia bangga dengan perstuan negara-negara Arab itu, kini ia dibingungkan dengan kecerai-beraiannya. Dari sinilah Shaḥrûr berkesimpulan bahwa negara-negara Arab membutuhkan teori untuk mengatur masyarakat (theories of society). ${ }^{4}$ Kesimpulannya itu muncul dari pergumulannya secara langsung dengan masyarakat Suriah dan Rusia yang sama sekali berbeda dalam hal pandangan dan gaya hidup mereka.

Pada tahun 1964, Shahrûr lulus dari Moscow Institute for Engineering. Ia kemudian kembali ke kampung halamannya, Damaskus. Namun empat tahun kemudian, tepatnya 1968, ia melanjutkan studinya ke University College, Dublin. Ia memperoleh gelar Master pada tahun 1969, dan gelar Doktor pada tahun 1972, keduanya dalam bidang teknik. ${ }^{5}$ Selama di Dublin, Shahrûr telah melahap pemikiran-pemikiran Alfred North Whitehead (1861-1947 M) -dan juga muridnya, Bertrand Russell (1872-1970 M), terutama yang tertuang dalam Science and the Modern World $^{7}$

\footnotetext{
${ }^{3}$ Muhammad Shahrûr, Wawancara (oleh Dale F. Eickelman), Damaskus, 1996, dalam Christmann (ed), The Qur'an, Morality and Critical Reason, 502.

${ }^{4}$ Muhammad Shahrûr, Wawancara, 505-506.

${ }^{5}$ Cristmann (ed), The Qur'an, Morality and Critical Reason, xx.

${ }^{6}$ Cristmann (ed), The Qur'an, Morality and Critical Reason, xxii.

${ }^{7}$ Lihat Alfred North Whitehead, Science and the Modern World (New York: Pelican Mentor Book, 1948), 1-212. Lihat juga, Muhammad Shạhrûr, Wawancara (Oleh Eickelman), 551.
} 
Andreas Cristmann menyebut bahwa Shạhrûr, lewat karya Whitehead tersebut, banyak terpengaruh dengan beberapa eksponen filsafat Positivisme Jerman, yakni Immanuel Kant (1724-1804 M), Johann Gottlieb Fichte (1762-1814 M) dan Wilhelm Hegel (1770-1831 M). Menurut Cristmann, sintesis antara filsafat spekulatif Whitehead, filsafat rasionalis-idealis Jerman dan struktur nalar matematis-teknis Shahrûr membentuk karakter tersendiri yang berbeda dari karakter para filsuf atau pemikir lainnya. ${ }^{8}$ Fenomena pemikiran Shahrûr memang unik dan jarang terjadi. Di akhir tahun masa tinggalnya di Dublin, tepatnya pada tahun 1972, Shahrûr mulai menuangkan pikarn-pikirannya dalam tulisan.' Namun ia tak dikenal sebagai penulis hingga tahun 1990-an.

\section{Konsep Sunah dan Hadis}

Muhammad Shahrûr mendefinisikan Sunah (sunnah) berbeda -bahkan berlawanan- dengan definisi sarjana Muslim pada umumnya yang tidak jarang menyinonimkan antara Sunah dan Hadis (badith). Ini bertolak dari pemahamannya bahwa hadis-hadis yang terekam dalam berbagai kitab Hadis kanonik, seperti Sabị̂̂ al-Bukbârî, Sabị̂̂ Muslim, Sunan Abî Dâwud dan lainnya, tidak bersumber dari wahyu Ilahi. Singkatnya, Shahrûr tetap mengakui "bahwa dasar bukum Islam adalah al-Kitâb dan al-Sunnah, tetapi bukan al-Kitâb dan al-Hadith."10 Setelah melakukan komparasi antara konsep Sunah yang diusung Shahrûr dan Fazlur Rahman (1919-1988) yang berkutat pada teori limit dan pendekatan double movement (gerak ganda), tidak berlebihan jika Fitria menyebut bahwa konsep Sunah versi Shahrûr "setingkat lebih berani dan liberal."11

Definisi Sunah memang harus dibedakan sama sekali dengan definisi Hadis. Tegasnya, Sunah dan Hadis itu berbeda. Hairillah, setelah mengutip pandangan Shaḥrûr tentang hakikat Sunah, menyimpulkan bahwa apa yang ditetapkan Rasulullah di Jazirah Arab pada abad ke-7

\footnotetext{
${ }^{8}$ Cristmann (ed), The Qur'an, Morality and Critical Reason, xxi-xxii. Dari kalangan sarjana Muslim klasik, Abdullah Saeed menyebut bahwa Shậûr terpengaruh oleh al-Farâbî (w. 338 H/ 950 M). Ia juga menyatakan bahwa Shahrûr berposisi sebagai "outsider" (orang luar) dalam penafsiran Alquran ditinjau dari segi profesinya. Lihat Abdullah Saeed, The Qur'an: An Introduction (New York: Routletge, 2008), 226.

${ }^{9}$ Karya-karya Shahrûr tentang ke-Islaman adalah al-Kitâb wa al-Qur'ân: Qirâ'ah Mu'âsirah, al-Islâm wa al-Îmân, Manz̧umat al-Qiyam, al-Dawlab wa al-Mujtama', Tajfîf Manâbi al-Irbâb dan Naḥwa Ușûl Jadîdah li al-Fiqh al-Islâmî.

${ }^{10}$ Muḥammad Shahrûr, al-Kitâb wa al-Qur'ân: Qirâ'ah Mu'âsirah (Damaskus: al-Ahâlî, 1990), 548.

11 Vita Fitria, "Komparasi Metodologis Konsep Sunnah menurut Fazlur Rahman dan Muhammad Shaḥrûr: Pespektif Hukum Islam," Asy-Syir'ab: Jurnal Ilmu Syariah dan Hukum 45, no. 2 (Desember 2011): 1335-1356.
} 
Masehi hanya sekadar alternatif pertama dalam menegakkan ajaran Islam. Oleh karena itu, apa yang ditetapkan itu bukanlah satu-satunya pilihan apalagi putusan terakhir. ${ }^{12}$ Distingsi antara keduanya ini terkadang tidak mendapat perhatian yang semestinya dari para sarjana Muslim yang secara langsung maupun tidak langsung menggeluti bidang kajian Hadis. Konsep Sunah yang digagas Shahrûr -sebagaimana dijelaskan berikutnyahendak menegaskan distingsi keduanya.

Dalam pandangan Shahrûr, pendapat yang menyatakan bahwa segala ucapan dan perbuatan Rasulullah merupakan wahyu yang didasarkan pada surah al-Najm: 3-4, "Wa mâ yantiqu 'an al-hawâ, in huwa illâ waby"un yûhâa (dan tiadalah yang diucapkannya itu (Al-Qur'an) menurut kemauan hawa nafsunya; ucapannya itu tiada lain hanyalah wahyu yang diwahyukan (kepadanya)," tidak dapat dibenarkan. Pronomina "buwa" secara gamblang merujuk pada Al-Qur'an, bukan kepada Rasulullah, serta sama sekali tidak berkaitan dengan pronomina di balik verba "yantiqu" yang memang merujuk pada diri Rasulullah. Konteks kedua ayat itu juga mengindikasikan bahwa yang dipersoalkan adalah keraguan orang-orang musyrik terhadap Al-Qur'an yang diturunkan kepada Rasulullah, bukan terhadap ucapan dan perbuatan beliau. ${ }^{13}$ Dengan ungkapan lain yang lebih sederhana, kedua ayat tersebut tidak hendak menyatakan bahwa segala ucapan Rasulullah adalah wahyu Ilahi, melainkan menegaskan bahwa Al-Qur'an adalah kalam Allah dan bukan perkataan pribadi Rasulullah yang terinspirasi dari hawa nafsu beliau.

Oleh karena ucapan dan perbuatan Rasulullah bukanlah wahyu Ilahi, maka beliau tidak memerintahkan -bahkan melarang- para sahabat untuk mencatatnya. Padahal, di waktu yang sama, Rasulullah menegaskan: "Aku telah meninggalkan kepada kalian sesuatu yang jika kalian mengikutinya, niscaya kalian tak akan tersesat selamanya: Kitab Allah (Al-Qur'an) dan Sunahku" (laqad taraktu fìkum mâ in ittaba tumûhu fa lan tadillû abad" : kitâb Allâh wa sunnatì.$^{14}$

\footnotetext{
${ }^{12}$ H. Hairillah, "Kedudukan al-Sunnah dan Tantangannya dalam Hal Aktualisasi Hukum Islam," Mazabib: Jurnal Pemikiran Hukum Islam 14, no. 2 (Desember 2015): 191-203.

${ }^{13}$ Lebih jauh Shahrûr mengemukakan beberapa contoh riil tentang ketidakwahyuan segala ucapan dan perbuatan Rasulullah. Diantara contoh itu adalah turunnya surah 'Abasa untuk menegur Rasulullah yang lebih memilih untuk menghormati pembedar-pembesar Quraysh yang bertamu ke kediaman beliau dari pada seorang Umm Maktûm yang buta dan hendak bertanya tentang urusan agama kepada beliau. Lihat Ibid., 545 .

14 Hadis sahih berdasarkan penelitian Nașir al-Dîn al-Albânî. Hadis itu, dengan berbagai rangkaian sanad dan matannya, diriwayatkan oleh: Malik b. Anas, al-Mwwatta', no. 3 (Beirut Dâr al-Iḥyâ' al-'Arabî, 1985), 2: 899; Aḥmad b. 'Amrw al-Bazzâr, al-Musnad, no.8993 (Madinah: Maktabat al-'Ulûm wa al-Hịkam, 1988-2009), 15: 385; 'Umar b. Aḥmad (Ibn Shâhîn), al-Targhî̉ fî̀
} 
Demikian juga para sahabat, setelah Rasulullah wafat, mereka tidak merasa perlu mengkodifikasikan hadis-hadis beliau. Mereka tidak melakukannya walaupun setelah merampungkan kodifikasi Al-Qur'an. ${ }^{15}$ Semua ini menunjukkan bahwa memang sebenarnya pencatatan dan kodifikasi Hadis tidak diperlukan, baik di masa Rasulullah, para sahabat maupun generasi-generasi setelahnya. ${ }^{16}$ Ini semakin mengindikasikan bahwa segala ucapan dan perbuatan Rasulullah memang tidak berasal dari wahyu Ilahi.

Dari sini, Shahrûr merasa perlu untuk melakukan redefinisi Sunah. Namun sebelum itu ia menjelaskan tentang dua dimensi penting dalam Islam: dimensi absolut (al-jânib al-mutlaq) dan dimensi relatif (al-jânib alnisbi). Dimensi absolut tidak lain hanyalah Allah yang menurunkan AlQur'an kepada Rasulullah, sedang dimensi relatif adalah Rasulullah sendiri yang mengaktualisasikan dimensi absolut tersebut dalam realitas yang melingkupinya. Dimensi wahyu yang bersifat absolut harus diaktualisasikan oleh Rasulullah dalam dimensi realitas yang bersifat relatif. Dimensi absolut mengantarkan Rasulullah sebagai seorang nabi (al-nabi), sedang dimensi relatif mengantarkan beliau menjadi seorang jenius (al-'abqari). Kejeniusan Rasulullah pada gilirannya akan terlampaui oleh perkembangan umat manusia dari zaman ke zaman. ${ }^{17}$

Dengan merelatifkan kejeniusan Rasulullah dalam mengaktualisasikan Al-Qur'an, maka "Islam akan menjadi relevan di segala ruang dan waktu". ${ }^{18}$ Oleh karenanya, definisi Sunah sebagai "segala yang bersumber dari Nabi Muhammad, baik perkataan, perbuatan, perintah, larangan atau persetujuan" adalah definisi yang keliru. Definisi Sunah yang benar, menurut Shahrûr, adalah "metode penerapan hukum-hukum Al-Qur'an secara mudah tanpa keluar dari batasan-batasan hukum Allah dalam

Fadẩil al-A'mâl wa Thawâb Dhâlike, no. 558 (Beirut: Dâr al-Kutub al-'Tlmiyyah, 2004), 152; 'Umar b. Aḥmad (Ibn Shâhîn), Sharḥ Madhâbib Abl al-Sunnah, no. 44 (t.tp: Mu'assast al-Qurḍubah, 1995), 41; 'Alî b. 'Umar al-Dâruquḍnî, al-Sunan, no. 4606 (Beirut: Mu’assasat al-Risâlah, 2004), 5: 440; Abû 'Abd Allâh al-Hâkim, al-Mustadrak 'ala al-Ṣahîhayn, no. 319 (Beirut: Dâr al-Kutub al'Ilmiyyah, 1990), 1: 172; Aḥmad b. al-Ḥusayn al-Bayhaqî, al-Sunan al-Kubrâ, no. 20337 (Beirut: Dâr al-Kutub al-'Ilmiyyah, 2003), 10: 195. Lihat juga Nâșir al-Dîn al-Albânî, Șahîh Jâmi al-Ṣaghîr wa Ziyâdatuh, no. 2937 dan no. 3232 (t.tp: al-Maktab al-Islâmî, t.th), 1: 566/ 615.

15 Menurut Shahrûr, dalih beberapa kalangan yang menyatakan bahwa tidak dikodifikasikannya hadis-hadis Rasulullah di masa beliau dan para sahabat disebabkan karena kekhawatiran akan tercampurnya Alquran dan Hadis merupakan argumentasi "konyol". Sebab Rasulullah adalah manusia pertama yang mengetahui bahwa Alquran sepenuhnya mendapat penjagaan langsung dari Allah—sebagaimana tertuang dalam al-Hijr : 9.

${ }^{16}$ Shạ̣rûr, al-Kitâb wa al-Qur'ân, 546-547.

${ }^{17}$ Shậûr, al-Kitâb, 547.

18 Shậûr, al-Kitâb, 548. 
persoalan-persoalan yang terkait dengan budûd (batas-batas), atau untuk menetapkan batasan-batasan yang bersifat lokal-temporal dalam persoalan-persoalan di luar budûd’. ${ }^{19}$

Poin "mempermudah" harus ditekankan di sini. Ini berdasarkan apa yang tertuang dalam surah al-Baqarah: 185, "Yurî̀u Allâh bikum al-yusrâ wa lâ yurî̀u bikum al-usr (Allah menghendaki kemudahan bagimu, dan tidak menghendaki kesukaran bagimu)" dan surah al-Hajj: 78, "Wa mâ ja'ala 'alaikum fi al-dîn min haraj (dan Dia sekali-kali tidak menjadikan untuk kamu dalam agama suatu kesempitan)." Selain itu, kata "sunnah" berasal dari kata "sanna" yang bermakna "yusr" (mudah) dan "jiryân bi subûlah (mengalir dengan lancar)." "20

Dalam pandangan Shahrûr, Sunah bukanlah segala perkataan dan perbuatan Rasulullah sebagaimana dipahami sebagian sarjana Muslim selama ini. Definisi yang disematkan pada Sunah itu agaknya lebih relevan jika diberikan pada Hadis. Hadis-hadis yang tercatat dalam kitabkitab Hadis kanonik yang jumlahnya mencapai puluhan ribu tak termasuk dalam kategori Sunah yang dimaksudkan Rasulullah ketika beliau menyatakan bahwa Al-Qur'an dan Sunah harus diikuti supaya tidak tersesat -sebagaimana dipaparkan di atas.

Setelah melakukan redefinisi Sunah, selanjutnya Shaḥrûr memformulasikan kategorisasi Sunah: Sunnat al-risâlab (Sunah kerasulan) dan Sunnat al-nubuwwah (Sunah kenabian).

\section{Sunnat al-Risâlah}

Shahrûr membagi Sunnat al-risâlah dilihat dari segi ketaatannya menjadi dua: ketaatan bersambung (al-tâ'ah al-muttasilah) dan ketaatan terputus (altâ'ah al-munfạsilab). Pertama, ketaatan bersambung. Ketaatan bersambung adalah ketaatan kepada Rasulullah yang bersambung dengan ketaatan kepada Allah. Contohnya adalah sebagaimana yang tertuang dalam surah Ali 'Imrân: 132, "Dan taatilah Allah dan Rasul, supaya kamu diberi rahmat" (wa ạtî̀u Allâh wa al-rasûl la' allakum turhamûn), serta al-Nisâ’: 69:

"Dan barangsiapa yang menaati Allah dan Rasul(Nya), mereka itu akan bersama-sama dengan orang-orang yang dianugerahi nikmat oleh Allah, yaitu: Nabi-nabi, para siddîqun, orang-orang yang mati syahid, dan orangorang saleh. Dan mereka itulah teman yang sebaik-baiknya" (wa man yuti" Allâh wa al-rasûl fa ulầika ma'a alladhina an 'ama Allâh 'alaybim min al-nabiyyina wa al-siddî̀în wa al-shubadâ' wa al-sâlibîn wa hasuna ulầika rafíqâa).

\footnotetext{
${ }^{19}$ Shahrûr, al-Kitâh, 549.
}

${ }^{20}$ Shahrûr, al-Kitâb, 549. 
Dalam konteks demikian, ketaatan kepada Rasulullah bersambung dengan ketaatan kepada Allah, baik sebelum ataupun sesudah beliau wafat. Ketaatan bersambung ini hanya khusus berkaitan dengan budûd (batas-batas hukum Allah), ibadah dan akhlak ${ }^{21}$-atau yang oleh Shạ̣rûr lazim disebut dengan al-sirật al-mustaqîm (jalan lurus).

Rasulullah, menurut Shạ̣rûr, telah merumuskan batas maksimal berkaitan dengan persoalan-persoalan hukum dalam Al-Qur'an yang hanya merumuskan batas minimal. Shahrûr, kemudian, mengemukakan beberapa contoh untuk menjelaskan konsep ketaatan bersambung ini. Di antara contoh-contoh itu adalah permasalahan pakaian wanita. Surah alNûr: 31 menyatakan:

"Katakanlah kepada wanita yang beriman: Hendaklah mereka menahan pandangannya, dan kemaluannya, dan janganlah mereka menampakkan perhiasannya, kecuali yang (biasa) tampak dari padanya. Dan hendaklah mereka menutupkan kain kerudung ke dadanya, dan janganlah menampakkan perhiasannya kecuali kepada suami mereka, atau ayah mereka, atau ayah suami mereka, atau putra-putra mereka, atau putra-putra suami mereka, atau saudara-saudara laki-laki mereka, atau putra-putra saudara lelaki mereka, atau putra-putra saudara perempuan mereka, atau wanita-wanita Islam, atau budak-budak yang mereka miliki, atau pelayanpelayan laki-laki yang tidak mempunyai keinginan (terhadap wanita) atau anak-anak yang belum mengerti tentang aurat wanita. Dan janganlah mereka memukulkan kakinya agar diketahui perhiasan yang mereka sembunyikan. Dan bertaubatlah kamu sekalian kepada Allah, hai orang-orang yang beriman supaya kamu beruntung" (wa qul li al-mu'minât yaghdubna min absâribinna wa yahfažna furûjabunna wa lâ yubdîna zinnatahunna illâ mâ .zahara minhâ wa lyadribna bi kbumûribinna wa lâ yubdîna ₹înatahunna illâ li bu'ûlatibinna

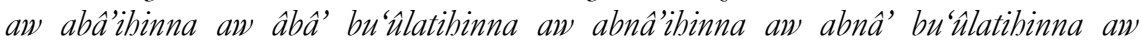
ikhwânibinna aw banî ikhwânibinna aw banî akhawâtibinna aw nisẩibinna aw mâ malakat aymânubunna aw al-tâbi îna ghayr ûlî al-irbah min al-rijâl aw al-tifl alladhîna lam yaž̉haru 'ala awrât al-nisâ' wa lâ yadribna bi arjulibinna li yu lama mâ yuk hfina min zînatibinna wa tûbû ila Allâh jamî'a" ayyuba al-mu'minûn la' allakum tuflibun).

Allah telah merumuskan batas minimal pakaian wanita, yakni yang sekarang disebut sebagai "pakaian dalam". Kemudian Rasulullah merumuskan batas maksimalnya sebagaimana tertuang dalam "hadis" demikian Shahrûr menyebutnya: "Seluruh badan wanita adalah aurat kecuali wajah dan kedua telapak tangannya" (kullu al-mar'ab 'awrah mâ 'adâ wajhihâ wa kaffayhâ). Menaati kata-kata yang dianggap "hadis" oleh

${ }^{21}$ Shahrûr, al-Kitâb, 550. 
Shaḥrûr ini sejajar dengan menaati ayat ke-31 dari surah al-Nûr di atas, tidak kurang dan tidak lebih. Jadi, jika seorang wanita berjalan di jalanan umum tanpa memakai sehelai benangpun, maka ia telah melampaui batas minimal yang dirumuskan Allah; dan jika ia memakai pakaian yang menutup seluruh badannya, termasuk wajah dan kedua telapak tangannya, maka ia telah juga keluar dari batas maksimal yang dirumuskan Rasulullah. Kesimpulannya adalah bahwa pakaian wanita harus bersesuaian dengan kebudayaan dan kearifan lokal masing-masing yang berkisar antara pakaian dalam dan pakaian yang menutupi seluruh badannya dengan pengecualian wajah dan telapak tangan. Mayoritas pakaian wanita di zamana modern ini, menurut Shạ̣rûr, sudah sesuai dan tidak keluar dari batasan-batasan minimal maupun maksimal yang telah dirumuskan Allah dan Rasul. ${ }^{22}$

Dalam perspektif Shạhûr, pakaian wanita yang menutupi seluruh badan kecuali wajah dan telapak tangan tidak dapat diaplikasikan kepada seluruh wanita di berbagai belahan dunia pada zaman modern ini. Letak geografis dan rentan waktu sangat mempengaruhi kelayakan dan kepantasan pakaian wanita. Mungkin, di zaman modern ini, masih ada orang-orang Arab yang menjunjung tinggi budaya klasik yang mengajarkan untuk menutup seluruh anggota tubuh wanita. Namun budaya Arab klasik itu tentunya tidak dapat diterapkan pada, misalnya, orang-orang Barat yang budaya berpakaian mereka jauh berbeda dengan budaya Arab klasik. Semua pakaian wanita dapat dikatakan sesuai dengan syariat, asalkan selaras dengan budaya dan kearifan lokal dalam berpakaian dan tidak keluar dari batasan-batasan yang telah ditentukan dalam Al-Qur'an dan Sunah.

Kedua, ketaatan terputus. Ketaatan terputus adalah ketaatan kepada Rasulullah yang terputus dengan ketaatan kepada Allah. Ini sebagaimana termaktub dalam surah al-Nisâ': 59 yang menyatakan:

"Hai orang-orang yang beriman, taatilah Allah dan taatilah Rasul (Nya), dan ulilamri di antara kamu. Kemudian jika kamu berlainan pendapat tentang sesuatu, maka kembalikanlah ia kepada Allah (Al-Qur'an) dan Rasul (Sunnahnya), jika kamu benar-benar beriman kepada Allah dan hari kemudian. Yang demikian itu lebih utama (bagimu) dan lebih baik

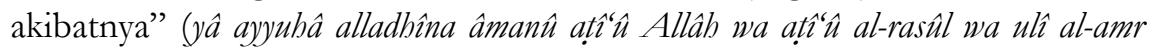
minkum fa in tanâza'tum fi shay' fa raddûbu ila Allâh wa al-rasûl in kuntum tu'minûna bi Allâh wa al-yawm al-âkbir, dhâlika khayr wa ahsanu ta'wîlà).

22 Shậûr, al-Kitâb wa al-Qur'ân, 550-551. 
Sebagaimana juga tertuang dalam surah al-Mầidah: 92, "Dan taatlah kamu kepada Allah dan taatlah kamu kepada Rasul-(Nya) dan berhatihatilah. Jika kamu berpaling, maka ketahuilah bahwa sesungguhnya kewajiban Rasul Kami, hanyalah menyampaikan (amanat Allah) dengan

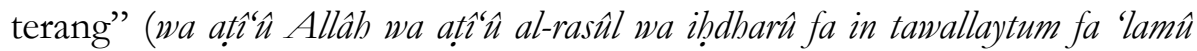
annamâ 'ala rasûlinâ al-balâgh al-mubîn).

Ketaatan terputus semacam ini hanya berlaku ketika Rasulullah masih dalam keadaan hidup, dan tidak berlaku lagi setelah beliau wafat. Yang termasuk dalam kategori ini adalah: perilaku-perilaku keseharian Rasulullah; hukum-hukum lokal-temporal (ạ̣kâm marḅaliyyah); keputusan-keputusan dalam kapasitas beliau sebagai kepala negara, hakim atau panglima perang; hukum-hukum pergaulan sosial, makanan, minuman atau pakaian yang kesemuanya diterapkan berdasarkan budaya dan kearifan lokal Arab dengan tanpa melangkahi batas-batas yang ditetapkan Al-Qur'an. Hadis-hadis yang diriwayatkan dari Rasulullah berkaitan dengan persoalan-persoalan demikian harus dipahami secara kontekstual, bukan tekstual. ${ }^{23}$ Tekstualisasi pemahaman hanya akan menjebak seseorang dalam kungkungan Arabisasi dan melupakan ajaranajaran dan nilai-nilai Islam yang sesungguhnya.

\section{Sunnat al-Nubuwwah}

Sunnat al-nubuwwah, menurut Shaḥrûr, terbagi menjadi dua macam. Pertama, hadis-hadis yang terkait dengan permasalahan-permasalahan gaib, yakni yang menjelaskan Al-Qur'an dan terkait dengan pemahaman yang umum terhadap Al-Qur'an. Hadis-hadis semacam ini harus selaras dengan konsep umum Al-Qur'an. Jika tidak, hadis-hadis itu dapat diabaikan. Kedua, hadis-hadis yang terkait dengan penjelasan perincian Al-Qur'an. Sama dengan yang pertama, hadis-hadis seperti ini harus sesuai dengan konsep umum Al-Qur'an.

\section{Problematika Kritik Hadis dan Kodifikasinya}

Setelah memastikan bahwa Hadis dengan berbagai definisinya yang berkembang selama ini bukanlah wahyu Ilahi, Shahrûr melangkah lebih jauh dengan menggugat otentisitas dan validitas hadis-hadis yang tercatat rapi dalam kitab-kitab Hadis kanonik, seperti Șahị̂ al-Bukbârî, Șahîh Muslim, Sunan Abî Dâwud, Sunan al-Tirmidhî, Sunan al-Nasầi dan Sunan Ibn Mâjah. Dengan tegas ia menyatakan bahwa kitab-kitab Hadis itu -serta berbagai catatan Hadis lainnya- muncul sebagai respons politik semata

\footnotetext{
${ }^{23}$ Shahrûr, al-Kitâb wa al-Qur'ân, 552.
} 
pada masa itu. Pergulatan dan pertarungan ideologi menyebabkan masing-masing kelompok merasa perlu untuk mengupayakan legitimasi dari hadis-hadis $\mathrm{Nabi}^{24}$ Oleh karenanya, meskipun suatu hadis telah dianggap memenuhi standardisasi kesahihan berdasarkan Ilmu Hadis, ia tidak serta merta dapat diterima secara mutlak.

Sikap kurang apresiatif terhadap Ilmu Hadis juga ditunjukkan oleh Shahrûr dengan menganggap bahwa kemunculannya dipenuhi faktorfaktor politik demi merobohkan pondasi kelompok-kelompok yang dianggap menyimpang dari Sunah, misalnya Muktazilah dan Syiah. Pada gilirannya, kelompok yang menamakan diri mereka sebagai Ahl alSunnah wa al-Jamâ'ah, atau Sunni, menjadikan Sunah dengan pengertian taklidnya sebagai senjata utama untuk meruntuhkan paham-paham kelompok yang berseberangan dengan mereka. ${ }^{25}$ Mungkin, dalam pandangan Shaḥrûr, umat Islam melakukan kesalahan fatal karena telah merumuskan Ilmu Hadis. Najmil Husna menegaskan bahwa Shaḥrûr memang hampir tidak pernah menyinggung kaidah-kaidah Ilmu Hadis dengan berbagai cabangnya sebagai suatu metodologi. ${ }^{26}$ Mungkin dari sinilah Aulassyahied berkesimpulan bahwa konsep Sunah Shạhrûr hanya "melahirkan kerancuan" dalam penerapan hukum Islam. ${ }^{27}$

Lebih jauh lagi, Shahrûr juga mengangkat permasalahan klasik yang menghiasi hampir seluruh buku-buku atau artikel-artikel yang menggugat otentisitas dan validitas Hadis: maksimalnya jumlah hadis yang diriwayatkan oleh Abû Hurayrah dan minimalnya jumlah hadis yang diriwayatkan oleh sahabat-sahabat dekat Rasulullah, seperti Abû Bakr alȘiddîq, 'Umar b. al-Khațtâb, 'Uthmân b. 'Affân dan Ali b. Abî TTâlib. Berdasarkan perspektif dan nalarnya, tidak masuk akal jika Abû Hurayrah yang persahabatannya dengan Rasulullah hanya berumur tiga tahun dapat melampaui riwayat-riwayat sahabat-sahabat dekat beliau. ${ }^{28}$ Namun sayangnya, Shahrûr tak menjabarkan lebih jauh tentang argumentasinya itu. Pasalnya, jika dikaji lebih mendalam, terdapat faktor-faktor logis dan rasional yang ditengarai menjadi pemicu maksimalnya jumlah periwayatan Abû Hurayrah dan minimalnya periwayatan sahabat-sahabat dekat Rasulullah.

\footnotetext{
24 Shậûr, al-Kitâb wa al-Qur'ân, 566.

${ }^{25}$ Lihat Shạnûr, al-Kitâb wa al-Qur'ân, 569.

26 M. Najmil Husna, "Kritik Matan Hadus Muḥammad Shậrûr," Jurnal al-Ikbtibar: Jurnal Pendidikan Islam 3, no. 2 (2016): 113-135.

${ }^{27}$ Qaem Aulassyahied, "Studi Kritis Konsep Sunnah Muhammad Shahrûr," Kalimab: Jurnal Studi Agama-Agama dan Pemikiran Islam 13, no. 1 (Maret 2015): 125-156.

${ }^{28}$ Shahrûr, al-Kitâb wa al-Qur'ân, 570.
} 
Dari sikap kurang apresiatif Shahrûr terhadap rumusan Ilmu Hadis di atas, tidak mengherankan jika ia selanjutnya menganggap sistem sanad dan kajian-kajian terhadapnya sebagai sesuatu yang kurang signifikan. Secara eksplisit Shahrûr memang tidak menyatakan demikian, namu itu dapat terlihat jelas dari berbagai pernyataan dan argumentasinya. Tujuan awalnya yang mengupayakan pemosisian Al-Qur'an sebagai tuntunan hidup umat Islam secara maksimal tanpa diintervensi oleh Hadis yang dianggap wahyu dan yang -bahkan- kadang menggeser posisi Al-Qur'an, mengantarkannya untuk bersikap demikian.

Dalam kritik Hadis, Shahrûr sama sekali tak menyinggung tentang penelitian sanad yang menjadi kajian paling urgen bagi mayoritas intelektual kesarjanaan Hadis. Untuk menilai otentisitas dan validitas suatu hadis, ia dengan terang-terangan membebek pandangan Jamâl alBanâ yang dikenal sebagai tokoh yang mengedepankan metode komparasi antara Al-Qur'an dan Hadis dalam memahami Hadis. Dengan demikian, keduanya jauh mengutamakan kritik matan dari pada kritik sanad, bahkan mungkin cenderung mengabaikan kritik sanad.

Jamâl al-Banâ, sebagaimana diungkapkan kembali oleh Shậrûr, banyak membekukan (me-mawqûf-kan) hadis-hadis yang dianggap bertentangan dengan Al-Qur'an. Ia, misalnya, membekukan hadis-hadis yang berbicara tentang hal-hal gaib, seperti kematian hingga hari kiamat, surga, neraka dan lain sebagainya. Hadis-hadis demikian, menurutnya, berseberangan dengan konsep umum Al-Qur'an: bahwa yang mengetahui hal-hal gaib hanyalah Allah semata. Adapun jika Rasulullah diberitahu hal-hal gaib tersebut, maka itu tidak untuk diceritakan kepada umatnya. ${ }^{29}$ Keduanya dengan tegas membekukan hadis-hadis demikian walaupun sanad-sanadnya dengan berbagai jalurnya (turuq) dianggap valid dari segi standardisasi Ilmu Hadis pada umumnya.

\section{Antara Kritik Sanad, Kontekstualisasi Pemahaman Hadis, dan Konsep Sunah Mụ̣ammad Shạ̣rûr}

Walaupun tidak menyatakannya secara eksplisit, namun secara implisit Shahrûr jelas tak mengakui standardisasi kesahihan Hadis yang meliputi

\footnotetext{
${ }^{29}$ Jamâl al-Banâ menyebutkan beberapa ayat Alquran yang dianggap menentang validitas hadishadis tersebut, yaitu al-A'râf : 187, Luqman : 34, al-Nâzi'ât : 42-44, Ali 'Imrân : 179, al-An'âm : 50, Yunus : 20, al-Naml : 65 dan al-Jinn : 26. Lebih lanjut lihat Muḥammad Shạhrûr, Naḥwa Ușûl Jadîd li al-Figh al-Islâmî (Damaskus: al-Ahâlî, 2000), 194-199. Jamâl al-Banâ, al-Sunnah wa Dawruhâ fi al-Figh al-Islâmî (Kairo: Dâr al-Fikr al-Islâmî, 1997), 249-260. Pandangan Jamâl al-Banâ tentang metode komparasi Al-Qur'an dan hadis ini telah dikaji oleh Umma Farida secara akademis. Lihat Umma Farida, "Metode Komparasi antara Hadis dan Alquran: Telaah atas Pemikiran Jamâl alBanâ tentang Kritik Matan" (Tesis_UIN Syarif Hidayatullah, Jakarta, 2005).
} 
sanad dan matan sekaligus -walaupun biasanya kritik sanad secara tergesa-gesa dianggap lebih mendapat perhatian lebih dan serius dari pada kritik matan. Bahwa suatu hadis harus mempunyai lima kriteria standar -yakni ketersambungan sanad, keadilan perawi, kedabitan perawi, ketiadaan shudhûdh (penyimpangan) dan ketiadaan illat (masalah)- tidak diperhitungkan oleh Shahrûr. Bahkan ia terlihat menyepelekan karyakarya sarjana Muslim klasik dalam bidang Hadis dan kritiknya.

Ini jelas membingungkan, sebab Shahrûr sebenarnya juga menjadikan Sunah sebagai dasar hukum. Sunah, dalam teori batasnya (ḅudûd), mempunyai peran signifikan untuk mengetahui batas maksimal yang ditetapkan oleh Rasulullah terhadap batas minimal yang ditetapkan oleh Allah dalam Al-Qur'an. Bagaimana kita bisa mengidentifikasi secara meyakinkan bahwa suatu batas maksimal benar-benar ditetapkan oleh Rasulullah jika kita mengenyampingkan-bahkan membuang-metode kritik Hadis sebagai proses dokumentasi Sunah, di mana kritik sanad merupakan bagian integral di dalamnya?

Dalam hal ritual peribadatan, misalnya salat, Shahrûr tetap berpendapat bahwa umat Islam harus mengkuti tata cara salat Rasulullah. Tata cara salat Rasulullah itu, menurutnya, sampai kepada umat Islam secara turun-temurun dan meyakinkan (mutawâtir), sebab ia berkesinambungan dan senantiasa diterapkan dari generasi ke generasi. Dengan ungkapan lain, tata cara salat itu sampai kepada umat Islam dengan penglihatan secara estafet, bukan dengan periwayatan. Pendapat Shạhrûr ini juga membingungkan. Pasalnya, bagaimana kita mengidentifikasi kedetailan tata cara salat -seperti syarat-syaratnya, rukurukunnya, sunah-sunahnya, yang wajib dan yang haram dikerjakan dalam salat, yang mubah dan yang makruh dikerjakan, dan lain sebagainya- jika perbuatan-perbuatan Rasulullah (aḥâdith filiyyah) tentang itu tidak diriwayatkan menggunakan sistem sanad?

Periwayatan Hadis dengan menggunakan sistem sanad yang sudah eksis sejak zaman Rasulullah walau dalam bentuk sederhananya dan berkembang pesat -bahkan dianggap sebagai bagian integral agama Islam- pada masa Muḥammad b. Sîrîn (w. 110 H) ${ }^{30}$ dan Muḥammad b. al-

\footnotetext{
30 Abû Bakr Muhammad b. Sîrîn, ia adalah seorang tabiin yang berkhidmat kepada Anas b. Mâlik. Ia juga merupakan ahli fikih kota Basrah. Lihat Abû 'Abd Allâh Muhammad ibn Ahmad ibn Abd al-Hâdî al-Dimshaqî, Țabaqât 'Ulamầ' al-Ḥadìth (Beirut: Muassasah al-Risâlah, 1996), 1: 151-152. Ia berkata: "Mereka sebelumnya tidak bertanya tentang sanad, namun setelah terjadi perang saudara, mereka berkata: 'Sebutkan perawi-perawi kalian'. Jika hadis tersebut diriwayatkan oleh penganut Sunah, maka ia diterima, sedang apabila diriwayatkan oleh ahli bidah, maka ia tertolak" (lam yakênû yas'alûna 'an al-isnâd, fa lammâ waqa' at al-fitnah, qâlû: sammû lanâ rijâlakum, fa yunz̧aru ilâ abl al-
} 
Mubârak (w. 118 H) ${ }^{31}$ merupakan suatu keunikan yang tidak dimiliki oleh umat-umat selain umat Muslim. ${ }^{32}$ Dalam dunia kritik sanad konvensional, penelitian yang ketat dan rumit harus dilakukan sebelum seorang perawi dinyatakan sebagai thiqah (terpercaya). Seorang yang dalam lingkungan masyarakatnya dikenal sebagai pembohong, periwayatan hadisnya tidak akan dapat diterima. Meskipun sebenarnya ia berlaku jujur dalam periwayatannya. Mengenai hal ini, Muḥammad Mușțafâ al-A'ẓamî menegaskan bahwa:

"Mereka, [yakni para kritikus Hadis], mengkritik ayah-ayah mereka, saudarasaudara mereka, teman-teman mereka dan keluarga dekat mereka. Dan, mungkin, itu (kritik sanad) adalah standar tertinggi yang memungkinkan yang dapat dilakukan untuk mendokumentasikan suatu sumber. Oleh karenanya, tidak ada alasan untuk menolak komentar-komentar para kritikus hadis yang semasa dengan para perawi." 33

Jika demikian realitasnya, seorang sarjana, baik Muslim maupun Barat, tidak selayaknya begitu saja mengeyampingkan kajian sanad jika ia hendak membahas apapun yang berkaitan dengan Hadis. Pasalnya, sanad telah 'terlanjur' menjadi bagian integral dari eksistensi Hadis, yang juga merupakan bagian integral dari Sunah. Apalagi, seperti pembacaan Amrulloh terhadap temuan Brown, kritik matan (kritik internal atau kritik teks) juga adalah bagian integral dari kritik sanad. Kritik matan dilakukan seiring sejalan dengan kritik sanad; hanya saja, dengan latar

sunnah fa yu'khadhu ḥadîthubum, wa yunz̧aru ilâ abl al-bida' fa lâ yu'khadhu haadîthubum). Lihat Riwayat Muslim b. al-Hajjâj al-Naysâbûrî, Muqaddimat al-Ṣahị̣ (Beirut: Dâr Ihyầ' al-Turâth al-'Arabî, t.th), 15.

31 Ia 'Abd Allâh b. al-Mubârak b. Wâdịh, Abû 'Abd al-Raḥman al-Ḥanẓalî. Abû Usâmah berkata: "Ia (Ibn al-Mubârak) bergelar amîr al-mu'minîn dalam dunia periwayatan hadis." Lihat al-Dimashqî, Tabaqât 'Ulamâ' al-Ḥadîth, 403-404. Ia berkata: "Sanad adalah bagian dari agama, seandainya tak ada sanad, seseorang akan berkata sesuka hatinya" (al-isnâd min al-dîn, wa law lâ al-isnâd, la qâla man shâ'a mâ shâ'a). Muslim, Muqaddimat al-Sahịh, 1: 15.

32 Sebagaimana pernyataan Ibn Qutaybah yang dikutip oleh Daniel Brown. Lihat Daniel Brown, Rethingking Tradition in Modern Islamic Thought (Cambridge: Cambridge University Press, 1999), 81.

33 Muhammad Muștafâ al-A'ẓamî, "Isnâd and its Significance" dalam Hadîth and Sunnah: Ideals and Realities, ed. P. K. Koya, et al. (Kuala Lumpur: Islamic Book Trust, 1996), 61. Untuk mengetahui keseriuasan para sarjana Muslim dalam memelihara Hadis dengan sistem sanad dan kritiknya, lihat empat artikel lainnya dalam antologi yang sama: (1) Muḥammad Zubayr Șiddîqî, "Ḥadîth: A Subject of Keen Interest", 3-22; (2) Muhammad 'Alî, "Collection and Preservation of Hadîth", 23-57; (3) Muhammad Zubayr Șiddîqî, "The Sciences and Critique of Hadîth”, 72-102; (4) S. M. Yusuf, "Sunnah: Its Development and Revision", 103-128. 
belakang yang bisa dipahami, kritik sanad dibingkai dalam bahasa kritik sanad. ${ }^{34}$

Pertanyaan mendasar selanjutnya adalah, bagaimana sikap seorang Muslim dalam merespons suatu hadis yang telah memenuhi standardisasi kesahihan: apakah ia dimaknai secara tekstual ataukah kontekstual? Dalam hal ini, pandangan Shahrûr -walaupun bukan pandangan orisinalnya- memang perlu dipertimbangkan dan diaplikasikan. Shaḥrûr menyatakan bahwa hadis-hadis yang tidak berkaitan dengan ibadah dan hudûd harus dipahami pesannya (madmûn), bukan harfiahnya (harfiyat alnaș.s..$^{35}$ Sekali lagi, sebenarnya pandangannya ini juga tidak dapat dilepaskan dari sistem sanad dan kritiknya yang seakan diabaikannya.

Sekarang adalah waktu yang tepat untuk memperbandingkan pemikiran Hadis Shạhûr dan pemikiran Hadis sarjana Muslim lainnya. Sosok yang paling relevan di sini, mungkin, adalah Yûsuf al-Qaraḍ̂âî, seorang sarjana Muslim yang tetap memperhitungkan sistem sanad namun juga terkenal dengan kontekstualisasi pemahamannya. Dalam pemahaman Hadis, al-Qaraḍ̂âî -tentunya setelah terpenuhi standardisasi kesahihannya- termasuk dalam kategori kontekstualis, terutama berkaitan dengan hadis-hadis sosial dan hubungan horizontal. Ia menyatakan bahwa pemahaman Hadis harus didasarkan pada latar belakang, situasi dan kondisi serta tujuan prinsipnya. ${ }^{36}$ Dengan metode pemahaman demikian, konklusi yang diambil dapat bertentangan dengan tekstualitas suatu hadis, namun tetap sejalan dan selaras dengan "rohnya". ${ }^{37}$ Dengan hanya berpegang pada tekstualitas Hadis, kadang pemahaman seseorang justru jauh dari pesan utama yang dimaksudkan penutur Hadis, yaitu Rasulullah.

Kontekstualisasi pemahaman Hadis -namun tak semuanya, terutama yang berkaitan dengan sosial dan politik, memang perlu dilakukan. Tekstualisasi pemahaman hanya akan membingungkan dan memberatkan umat Islam yang hidup di zaman modern. Zaman Rasulullah di Jazirah Arab tentunya jauh berbeda dengan zaman modern di berbagai belahan dunia. Salah satu contoh kontekstualisasi pemahaman al-Qaraḍ̂âî adalah

\footnotetext{
34 Lihat Amrulloh, "Eksistensi Kritik Matan Masa Awal: Membaca Temuan dan Kontribusi Jonathan Brown," Kontemplasi: Jurnal Ilmu-Ilmu Ushuluddin 4, no. 1 (Agustus 2016): 1 dan seterusnya.

35 Shậrûr, al-Kitâb wa al-Qur'ân, 570-571.

36 Yûsuf al-Qaraḍ̂âî, Kayf Nata'âmal ma' al-Sunnah al-Nabawiyyah (Kairo: Dâr al-Shurûq, 2006), 145.

37 "Rûh al-Sunnah" adalah istilah al-Qarḍ̂wî̀ untuk membahasakan pesan utama yang dimaksudkan oleh Rasulullah dalam hadis-hadis beliau. Lihat ibid., 155.
} 


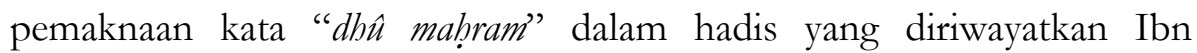
"Abbâs: "Janganlah seorang wanita bepergian jauh kecuali bersama mahramnya" (lâ tusâfiru al-mar'ah illâ ma'a dhî maḥram) dengan "sistem keamanan". Jika sistem keamanan telah memadai dan seorang wanita dirasa aman untuk bepergian jauh tanpa mahram atau suaminya, maka ia diperkenankan untuk melakukannya. Namun jika sistem keamanan tidak memadai dan seorang wanita dirasa tidak aman untuk bepergian jauh, maka ia tidak diperkenankan melakukannya. ${ }^{39}$ Konklusi ini ditarik dengan memperhatikan situasi dan kondisi di mana hadis tersebut disabdakan, dan selanjutnya dapat diketahui bahwa tujuan prinsip Rasulullah adalah untuk melindungi kaum Hawa dengan penekanan adanya keamanan yang jelas.

\section{Kesimpulan}

Muhammad Shahrûr mempunyai pandangan berbeda dengan sarjana Muslim pada umumnya, khususnya tradisionalis (abl al-hadith), tentang Sunah -walaupun sebenarnya pandangan-pandangannya bukan hal baru yang tidak pernah dinyatakan pendahulunya. Pandangan Shahrûr yang berkaitan dengan pemahaman materi Hadis perlu untuk digemakan dan diaplikasikan dengan teliti dan hati-hati. Pasalnya, kontekstualisasi pemahaman Hadis merupakan keniscayaan demi menghasilkan konklusi yang tepat dan proporsional. Pandangan kontekstualisasi pemahaman Shahrûr tersebut juga bukan hal baru. Sebelumnya, telah banyak sarjana Muslim, baik tradisionalis (abl al-hadith) ataupun -lebih-lebih- rasionalis (ablal-ra'y), yang menerapkannya.

Sikap kurang apresiatif Shahrûr terhadap kritik Hadis dengan segala cabangnya -seperti sistem sanad, jarḥ wa ta'dîl (komentar negatif dan komentar positif -dalam konteks periwayatan Hadis), tabaqât (strata) ahli Hadis dan lain sebagainya- tidak patut diapresisi. Shậûr mendorong umat Islam agar menjadikan materi-materi Hadis yang selain permasahan ibadah dan ḥudûd sebagai metode pemecahan masalah. Dengan kata lain, yang harus diperhatikan adalah cara Rasulullah menyelesaikan masalah, bukan materi penyelesaian itu sendiri. Untuk mengetahui cara Rasulullah

\footnotetext{
38 Hadis sahih, diriwayatkan oleh: Muhammad b. Ismâcîl al-Bukhârî, al-Jâmi al-Ṣậhh, no. 1086, 1087 dan 1197 (Manșûrah: Dâr Dûq al-Najâh, 1422 H), 2: 43 dan 61; no. 1862, 3: 19; Muslim, alSậ̣̂h, no. 1338, 2: 975-976; Abu Dâwud al-Sijistânî, al-Sunan, no. 1727 (Beirut: al-Maktabah al'Așriyyah, t.th), 2: 140; Muḥammad b. 'Îsâ al-Tirmidhî, al-Sunan, no. 1169 (Mesir: Shirkat Maktabah wa Mạ̣ba'ah Muṣḍafâ al-Bâbî al-Hạlbî, 1974), 3: 464; Ibn Mâjah al-Qazwînî, al-Sunan, no. 2898 (Aleppo: Dâr Ihyâ’ al-Kutub al-'Arabiyyah, t.th), 2: 968.

${ }^{39}$ Lihat al-Qaradâwî, Kayf Nata'âmal ma'a al-Sunnah, 149.
} 
menangani masalah dengan tanpa masalah, seseorang tidak dapat begitu saja lepas dari metode kritik Hadis -di mana kritik sanad adalah bagian integral di dalamnya- yang dirancang untuk menyeleksi mana yang benarbenar datang dari Rasulullah dan mana yang tidak. Oleh karenanya, sebenarnya gugatan Shahrûr terhadap eksistensi Ilmu Hadis dan sikap kurang apresiatifnya terhadap sistem sanad tidak perlu dilakukan. Yang perlu dilakukan adalah kontekstualisasi pemahaman.

\section{Daftar Pustaka}

A'ẓamî (al), Muḥammad Muṣtafâ. "Isnâd and its Significance” dalam Hadith and Sunnah: Ideals and Realities. Ed. P. K. Koya, et al. Kuala Lumpur: Islamic Book Trust, 1996.

Albânî (al) Muhammad Naṣir al-Dîn. Șahîh Jâmi al-Ṣaghîr wa Ziyâdatuh. T.tp: al-Maktab al-Islâmî, t.th.

Amrulloh. "Eksistensi Kritik Matan Masa Awal: Membaca Temuan dan

Kontribusi Jonathan Brown," Kontemplasi: Jurnal Ilmu-Ilmu Ushuluddin 4, No. 1 (Agustus 2016).

Aulassyahied, Qaem. "Studi Kritis Konsep Sunnah Muhammad

Shahrûr," Kalimab: Jurnal Studi Agama-Agama dan Pemikiran Islam 13, no. 1 (Maret 2015).

Banâ (al), Jamâl. Al-Sunnah wa Dawruhâ fi al-Fiqh al-Islâmî. Kairo: Dâr alFikr al-Islâmî, 1997.

Bayhaqî (al), Aḥmad ibn al-Husayn ibn 'Alî. Al-Sunan al-Kubrâ. Beirut: Dâr al-Kutub al-'Ilmiyyah, 2003.

Bayhaqî (al). Al-Sunan al-Saghîr. Beirut: Dâr al-Kutub al-'Ilmiyyah, 2003.

Bazzâr (al), Abû Bakr Aḥmad ibn 'Amr. Al-Musnad. Madinah: Maktabat al-'Ulûm wa al-Hikam, 1988-2009.

Brown, Daniel. Rethingking Tradition in Modern Islamic Thought. Cambridge: Cambridge University Press, 1999.

Bukhârî (al), Abu 'Abd Allâh Muhammad ibn Ismâ‘̂îl. Al-Jâmi' al-Ṣahị̂h. Manșûrah: Dâr Tûuq al-Najâh, 1422 H.

Christmann, Andreas (ed), The Qur'an, Morality and Critical Reason: The Essential Muhammad Shahrur. Leiden: Brill, 2009.

Dâruquṭî (al), Abû al-Ḥasan Alî ibn'Umar. Al-Sunan. Beirut: Mu'assasat al-Risâlah, 2004.

Dimshaqî (al), 'Abd Allâh Muhammad ibn Ahmad ibn Abd al-Hâdî. Tabaqât 'Ulamâ al-Hadîth. Beirut: Muassasah al-Risâlah, 1996. 
Farida, Umma. "Metode Komparasi antara Hadis dan Al-Qur'an: Telaah atas Pemikiran Jamâl al-Banâ tentang Kritik Matan". Tesis-UIN Syarif Hidayatullah, Jakarta, 2005.

Fitria, Vita. "Komparasi Metodologis Konsep Sunnah menurut Fazlur Rahman dan Muḥammad Shaḩrûr: Pespektif Hukum Islam," AsySyir'ab: Jurnal Ilmu Syariab dan Hukum 45, no. 2 (Desember 2011).

Hairillah, H. "Kedudukan al-Sunnah dan Tantangannya dalam Hal Aktualisasi Hukum Islam," Mazabib: Jurnal Pemikiran Hukum Islam 14, no. 2 (Desember 2015).

Hâkim (al), Abû 'Abd Allâh. al-Mustadrak 'ala al-Ṣaḅ̂hbayn. Beirut: Dâr alKutub al-'Ilmiyyah, 1990.

Husna, M. Najmil. "Kritik Matan Hadus Muḥammad Shaḥrûr," Jurnal alIkbtibar: Jurnal Pendidikan Islam 3, no. 2 (2016).

Ibn Mâjah, Abû 'Abd Allâh Muḥammad ibn Yazîd. Al-Sunan. Hạab: Dâr Ihyầ' al-Kutub al-'Arabiyyah, t.th.

Ibn Shâhîn. Al-Targhîb fî Fadẩil al-A'mâl wa Thawâb Dhâlik. Beirut: Dâr al-Kutub al-'Ilmiyyah, 2004.

Ibn Shâhîn. Sharḥ Madhâhib Abl al-Sunnah. T.tp: Mu'assast al-Qurțubah, 1995.

Mâlik ibn Anas. Al-Muwatta’' Beirut Dâr al-Ihyầ’ al-'Arabî, 1985.

Muslim b. al-Hajijầj. Kitâb al-Ṣaḥiḥ. Beirut: Dâr Ihyyâ' al-Turâth al-'Arabî, t.th.

Qaraḍ̂âî (al), Yûsuf. Kayf Nata'âmal ma' al-Sunnah al-Nabawiyyah. Kairo: Dâr al-Shurûq, 2006.

Saeed, Abdullah. The Qur'an: An Introduction. New York: Routletge, 2008.

Shậrûr, Muhammad. al-Kitâb wa al-Qur'ân: Qirâ'ah Mu'âsirah. Damaskus: al-Ahâlî, 1990.

Shạhrûr, Muḥmmad. Naḥwa Ușûl Jadîd li al-Fiqh al-Islâmî. Damaskus: alAhâlî, 2000.

Sijistânî (al), Abu Dâwud. Al-Sunan. Beirut: al-Maktabah al-'Așriyyah, t.th.

Tirmidhî (al), Abû 'Îsâ. Al-Sunan. Mesir: Shirkat Maktabah wa Maṭba'ah Muștafâ al-Bâbî al-Halbî̀, 1974.

Whitehead, Alfred North. Science and the Modern World. New York: Pelican Mentor Book, 1948. 